Ann. Biol. anim. Bioch. Biophys., 1977, 17 (3 A), 249-258.

\title{
Relationships between fatty acid composition of body lipids and lipid mobilization in rat. I. A study of carcass lipids.
}

par Y. DEMARNE, Maïmouna TOURE, J. FLANZY, Marie-José LECOURTIER

Station de Recherches de Nutrition, I.N.R.A. 78350 Jouy-en-Josas, France

Summary. The biochemical kinetics of different body compartments (lipid, water and protein), and especially of body lipid stores, is studied in 2 types of young, non-obese male rats during weight loss from $300 \mathrm{~g}$ to $250 \mathrm{~g}$, then from $250 \mathrm{~g}$ to $200 \mathrm{~g}$. Percentages of oleic acid $\left(C_{18: 1 \omega 9}\right)$ and linoleic acid $\left(C_{18: 2 \omega 6}\right)$ in body lipids differ in the two types of animals fed lard or sunflower-seed oil. Using identical energy restriction, weight decrease kinetics are the same in the two groups. Biochemical results for weight loss in the 2 successive periods differ distinctly, but are expressed in the same way for the two types of rats. As concerns body lipids between 300 and $200 \mathrm{~g}, 90$ p. 100 of neutral lipids and 20 p. 100 of phospholipids are catabolized, while amounts of unsaponifiable lipids remain stable. Over the whole experimental period, the composition of catabolized fatty acid mixtures represents the initial compositions of the two types of body lipid stores. There is no preferential catabolism, some fatty acids being stored at the cost of others; linoleic acid $\left(C_{18: 2 \omega 6}\right)$, in spite of its essential fatty-acid character, seems to be catabolized in the same way as oleic acid $\left(C_{18: 1 \omega 9}\right)$ in conditions of energy restriction. The presence of a high level of linoleic acid in body stores (45 p. 100 of total fatty acids resulting from sunflower-seed oil feeding) does not seem to be a nutritional factor modifying the kinetics of weight decrease and lipolysis.

\section{Introduction.}

Introducing sunflower-seed oil into the diet (Demarne et al., 1975) as 20 p. 100 of the overall energy supply does not quantitatively alter lipogenesis and proteinogenesis in the young growing rat.

However, it does cause the formation of body lipids rich in unsaturated fatty acids and containing up to 48 p. 100 of linoleic acid $\left(C_{18: 2 \omega_{6}}\right)$. Incorporation of a large amount of linoleic acid, first in the diet and then in adipose store triglycerides, raises some questions, especially as concerns its further use in catabolization. Some authors think that high linoleic acid concentrations in fat tissue change animal metabolism under energy restriction. This would be particularly expressed by slower weight loss than the controls and by marked differences in respiratory exchanges (Jacquot ef al., 1959). The preferential retention of linoleic acid during fasting has been reported (Raulin and Launay, 1964 ; Raulin ef al., 1965). 
On the other hand, some authors think that linoleic acid, in spite of special physiological properties related to its essential fatty acid characteristics, undergoes the same catabolism as other long-chain fatty acids present in body triglycerides (Hirsch, 1961 ; Longenecker, $1939 a$; Stein and Stein, 1962).

Considering the divergence of opinion in the literature, we wished to compare body compartment balances in rat fed sunflower-seed oil or lard when energy restriction leads to considerable body weight decrease.

\section{Material and methods.}

Dief and experimental procedure.

Forty Wistar rats from the same rat-room and weaned in the same conditions ( 8 young per mother) were used. The mean weight of the animals at the beginning of the experiment was $66.5 \mathrm{~g}$. They were divided into 2 lots ( $L$ and $S$ ) of 20 subjects each and fed either diet $L$ (containing lard) or diet $S$ (containing sunflower-seed oil).

The percentage composition of the diets was the following : 18.1 Norwegian fish meal + DL methionine ; 22.0 sugar ; 43.9 cornstarch ; 10.0 fat ; 1.0 vitamin mixture ; 3.0 mineral mixture; 2.0 agar-agar. The fats introduced into the diets were lard (growth diet L), sunflower-seed oil (growth diet S) and peanut oil (weight loss diet P). Lipid fatty acid compositions of the 3 diets are shown in Table 1 . The animals in both

\section{TABLE 1}

Lipid fatty acid composition of different diets (values shown in p. 100 of methylic esters assayed)

\begin{tabular}{ccrrrrr}
\hline Dists & $\mathrm{C}_{14: 0}$ & $\mathrm{C}_{16: 0}$ & $\mathrm{C}_{10: 1}$ & $\mathrm{C}_{18: 0}$ & $\mathrm{C}_{18: 1}$ & $\mathrm{C}_{18: 2 \omega 6}$ \\
\hline $\mathrm{L}$ & 2.4 & 30.2 & $2.5^{*}$ & 20.5 & $36.4^{*}$ & 8.0 \\
\hline $\mathrm{S}$ & 0.8 & 7.7 & 0.5 & 6.4 & 23.7 & 60.9 \\
\hline $\mathrm{P}$ & traces & 10.8 & 0.6 & 6.5 & 56.5 & 25.6
\end{tabular}

* $\omega 7$ and $\omega 9$ isomere mixture (developed by GLC through a capillary column).

lots ingested the same amounts of feed. When they reached a mean weight of $300 \mathrm{~g}$, 7 rats from each lot were chosen at random and killed in a state of non-repletion. The 13 rats remaining in each lot were fed the same diet $P$ starting on that day. However, the daily energy supply (carbohydrates and lipids) was restricted while a normal supply of protein, minerals and vitamins was given, based on feed consumption of the animals during growth. Daily weight loss induced was equivalent to the mean growth rate observed in each of the lots between $66.5 \mathrm{~g}$ and $300 \mathrm{~g}(6.5 \mathrm{~g} /$ day $)$. When mean weight of the rats reached about $250 \mathrm{~g}, 6$ were selected at random in each lot and 
killed. The 7 subjects remaining in each lot continued weight loss to $200 \mathrm{~g}$, when they were killed. The same energy restriction was applied to rats in both lots when they dropped from 300 to $200 \mathrm{~g}$.

\section{Analytical methods.}

The animals were decapited ; the livers were separated from the rest of the carcass, then weighed. The bloodless carcasses were weighed, plunged into liquid nitrogen, ground in a "Scharfen »-type grinder and then freeze-dried and stored at $-80^{\circ} \mathrm{C}$ until analysis.

Amounts of water in the carcass were estimated by weighing before and after freeze-drying and verified by desiccation of corresponding samples in a thermoregulated oven $\left(65^{\circ} \mathrm{C}\right)$ until constant weight. Quantities of total nitrogen $(N \times 6.25)$ were determined by nitrogen assay using Kjeldahl's technique. Total carcass and liver lipids were extracted at room temperature according to the method of Floch, Lees and Sloane-Stanley (1957).

Phospholipids were separated from neutral lipids by 2 chromatographies on a silicic acid column using the technique proposed by Kates (1972). The silicic acid, washed in water, acetone, and ether, was reactivated for 2 hours at $105^{\circ} \mathrm{C}$; celite 535 was then added (1/3 of its weight). Neutral lipids were eluted by $200 \mathrm{ml}$ distilled chloroform, and the phospholipids by $200 \mathrm{ml}$ distilled methanol. The purity of the 2 fractions was checked by thin-layer chromatography.

Unsaponifiable lipids were extracted by distilled hexane after saponification of total lipids. The fatty acids of different lipid fractions, thus separated from other lipidic components, were methylated then identified and assayed by gas liquid chromatography. The analytical conditions were : Girdel apparatus 75F-D2 ; column length : $3 \mathrm{~m}$; diameter : $1 / 8$ inch ; stationary phase : EGSS $\times(5$ p. 100) on Chromosorb GDMCS 80/100 mesh ; carrier gas : nitrogen ; column temperature : $170^{\circ} \mathrm{C}$ and flame ionization detection. An Infotronics CRS 100 electronic integrator was used to compute peak aera.

\section{Results.}

Given the same energy restriction, the animals of both lots had the same weight loss. Their loss of 33 p. 100 of initial weight in 16 days was linear :

$$
P(g)=300-6.25 t(d) \text {. }
$$

Table 2 shows the composition of the bloodless carcasses without livers. At the end of the growth period $(300 \mathrm{~g})$, the rats of lots $L$ and $S$ had identical amounts of total proteins $(\mathrm{N} \times 6.25)$. Lot $\mathrm{S}$ animals had a slightly higher amount of lipids than lot $L(+7 \mathrm{~g})$, while the inverse was true for water. This is in relation with the digestion balance presented in table 3. When identical quantities of dry matter were ingested (taking into account differences in lipid digestibility : 90 p. 100 for lard, 97 p. 100 for sunflower-seed oil), lot $S$ rats absorbed about $7 \mathrm{~g}$ more of lipids than lot $L$ animals during the growth period. Carcasses richer in lipids were poorer in water; the two 
phenomena counterbalance one another, and there is no difference in growth. At $250 \mathrm{~g}$ and at $200 \mathrm{~g}$, carcass compositions were similar in both lots.

Water, protein and lipid balances are shown in table 4 . From 300 to $250 \mathrm{~g}(16.5$ p. 100 of weight loss) water loss is higher in lot $L$ than in lot $S$; protein loss is not signi-

TABLE 2

Water, protein $(\mathrm{N} \times 6,25)$ and lipid composition of carcass (mean values $\pm \mathrm{Sm}$ )

\begin{tabular}{|c|c|c|c|c|c|}
\hline $\begin{array}{l}\text { Slaughter } \\
\text { weight }(g)\end{array}$ & Lots & $\begin{array}{c}\text { Carcass } \\
\text { weight }(g)\end{array}$ & $\begin{array}{l}\text { Water } \\
\text { (p. 100) }\end{array}$ & $\begin{array}{c}N \times 6,25 \\
(\text { p. } 100)\end{array}$ & $\begin{array}{l}\text { Lipids } \\
\text { (p. 100) }\end{array}$ \\
\hline \multirow{2}{*}{300} & $\mathbf{L}$ & $270.2 \pm 8.6$ & $60.9 \pm 0.8 *$ & $17.2 \pm 0.5$ & $16,9 \pm 1.2 *$ \\
\hline & $S$ & $272.3 \pm 6.6$ & $58.7 \pm 0.5 *$ & $16.7 \pm 0.5$ & $20.0 \pm 0.5 *$ \\
\hline \multirow{2}{*}{250} & $L$ & $234.4 \pm 10.7$ & $66.5 \pm 0.3$ & $20.5 \pm 0.3$ & $7.9 \pm 0.4$ \\
\hline & $S$ & $233.3 \pm 8.4$ & $67.2 \pm 0.8$ & $20.6 \pm 0.6$ & $7.1 \pm 0.7$ \\
\hline \multirow{2}{*}{200} & $\mathbf{L}$ & $181.9 \pm 3.3$ & $69.2 \pm 0.6$ & $22.0 \pm 0.5$ & $3.9 \pm 0.6$ \\
\hline & $S$ & $189.4 \pm 5.5$ & $68.9 \pm 0.3$ & $21.3+0.3$ & $3.9 \pm 0.5$ \\
\hline
\end{tabular}

* Difference between lots $S$ and $T$ statistically significant $(p \leqslant 0,05)$.

ficant. However, there are large lipid losses in both lots. Highest mobilization is found in lot $S$ (the richest in lipids at $300 \mathrm{~g}$ ). In both cases, carcass weight loss is entirely related to total losses in lipids and water. The compensation between « water » and " lipid » compartments during this period explains why the carcasses of both lots have identical compositions at $250 \mathrm{~g}$.

TABLE 3

Lipid ingestion and absorption balances during growth

\begin{tabular}{ccccc}
\hline Lots & $\begin{array}{c}\text { Drymatter } \\
\text { ingested }(g)\end{array}$ & $\begin{array}{c}\text { Lipids } \\
\text { ingested }(g)\end{array}$ & $\begin{array}{c}\text { Apparent* } \\
\text { digestibility } \\
(\mathrm{p} .100)\end{array}$ & $\begin{array}{c}\text { Lipids } \\
\text { absorbed }(g)\end{array}$ \\
\hline $\mathrm{L}$ & 626,8 & 67.1 & 89.9 & 60.3 \\
\hline $\mathrm{S}$ & 627.1 & 68.0 & 97.2 & 67.1 \\
\hline
\end{tabular}

* From Demarne ef al. (1975).

From $250 \mathrm{~g}$ to $200 \mathrm{~g}$ (20 p. 100 of weight loss), the rats of both lots have the same amounts of water, proteins and lipids. Weight loss of the «lipid » compartment is 3 to 4 times less than from 300 to $250 \mathrm{~g}$. However, the « water » compartment shows a 
large weight loss while significant proteolysis begins. Over the whole weight loss period, body lipid loss is slightly higher in lot $S$ which was initially fatter ; water loss is higher in the thinner lot L. Protein losses are the same in both lots.

TABLE 4

Water, protein and lipid balance during weight loss (mean values shown in grams)

\begin{tabular}{cccccc}
\hline Periods & Lots & Carcasses & Water & N $\times 6.25$ & Lipids \\
\hline $300-250$ & $\mathrm{~L}$ & $-35,8$ & $-8.9^{*}$ & +1.6 & $-27.5^{*}$ \\
\hline \hline $\mathrm{S}$ & $-39,0$ & -3.1 & +2.7 & $-37.8^{*}$ \\
\hline $250-200-$ & $\mathrm{L}$ & -52.5 & $-29.6^{*}$ & $-7.8^{*}$ & $-11.2^{*}$ \\
\hline $\mathrm{S}$ & -43.9 & $-25.9^{*}$ & $-8.0^{*}$ & $-9.6^{*}$ \\
\hline $300-200-$ & $\mathrm{L}$ & -88.3 & $-38.5^{*}$ & $-6.2^{*}$ & $-38.7^{*}$ \\
\hline $\mathrm{S}$ & -82.9 & $-29.0^{*}$ & $-5.3^{*}$ & $-47.4^{*}$
\end{tabular}

* Variation statistically significant for the same lot of rats during the period under consideration $(P \leqslant 0,05)$.

Figure 1 shows the amounts of neutral lipids, phospholipids, total fatty acids and unsaponifiable lipids. At $300 \mathrm{~g}$, neutral lipids compose about $95 \mathrm{p}$. 100 of total body lipids. During weight loss total lipid composition varies; neutral lipid concentration decreases and that of phospholipids increases in both lots. At the same time, total fatty acid concentration decreases and that of unsaponifiable lipids increases. Neutral lipids are thus very highly mobilized while phospholipids are much less affected by the process. The amounts of unsaponifiable lipids are apparently unaltered during weight loss.

About 90 p. 100 of all the initial stores of total fatty acids in the carcass are catabolized in both lots between 300 and $200 \mathrm{~g}$. Fatty acid composition of total carcass lipids in shown in table 5 . At $300 \mathrm{~g}$, the results are comparable to those presented previously (Demarne et al., 1975). In the carcasses of animals receiving lard (lot L), oleic acid $\left(C_{18: 1}\right)$ is found in higher amounts than other fatty acids, while linoleic acid $\left(C_{18: 2}\right)$ is present in larger quantities in the carcasses of rat fed the sunflower-seed oil.

When rats of both lots reach $250 \mathrm{~g}$, no large variations in total lipid fatty acid composition are found as compared to those observed at $300 \mathrm{~g}$. As compared to the two previous stages, myristic $\left(C_{14: 0}\right)$ and palmitic $\left(C_{16: 0}\right)$ acid concentration are unchanged at $200 \mathrm{~g}$. However, palmitoleic acid $\left(C_{16: 1}\right)$ content in both lots, oleic acid $\left(C_{18: 1}\right)$ concentration in lot $L$ and linoleic acid $\left(C_{18: 2}\right)$ concentration in lot $S$ decrease. In both lots stearic acid $\left(\mathrm{C}_{18: 0}\right)$ content increases, and apparently long-chain polyunsaturated fatty acid $\left(\geqslant C_{20}\right.$ ) concentrations are also higher. An explanation may be that at this stage more than 30 p. 100 of body lipids are in the form of phospholipids. Their fatty acid compositions are shown in table 6.

Knowing the amounts of total carcass fatty acids at each stage (fig. 1) and their 
composition percentages (table 5), catabolized fatty acid can be evaluated. The composition of the whole of the fatty acids catabolized in each lot between each stage studied may then be obtained. The results are given in table 7. During the first weight loss
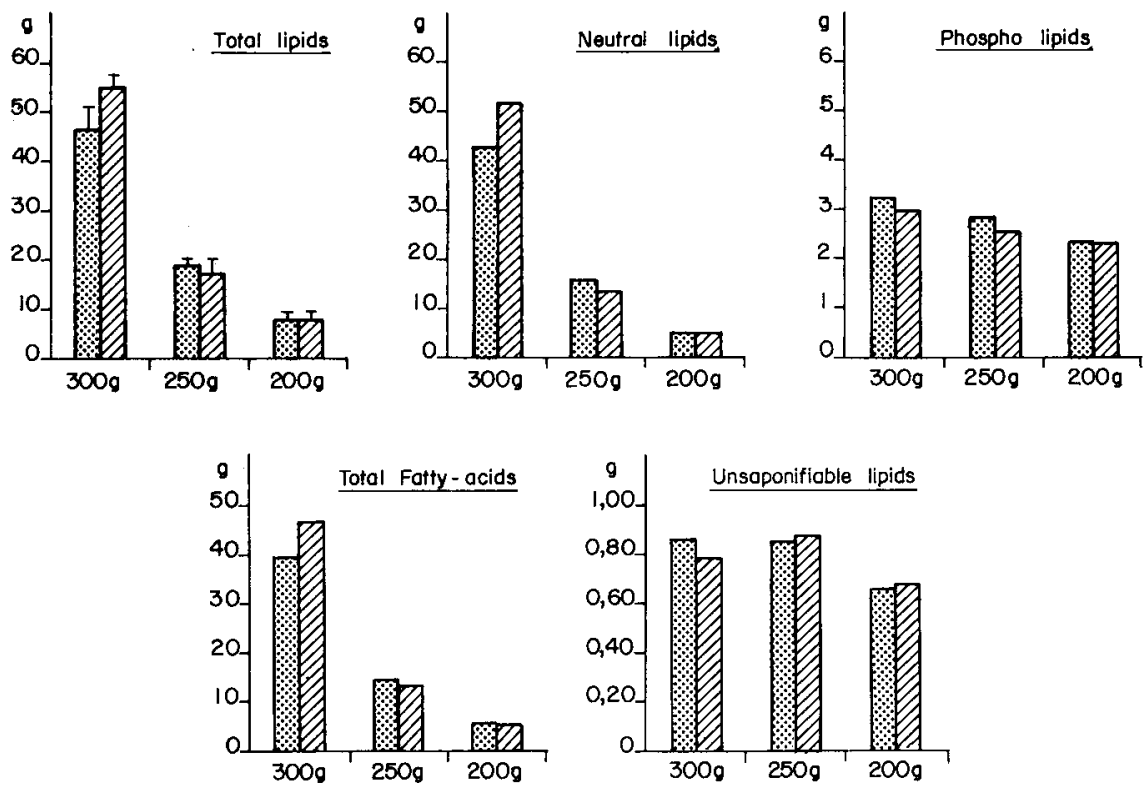

Lard

EIIC Sunflower-seed oll

FIG. 1. - Evolution of total lipids, neutral lipids, phospholipids, fatty acids and unsaponifiable lipids contained in the carcass (values expressed in grams).

period (16.5 p. 100 of weight loss), the fatty acid compositions of calabolized mixtures in each lot are identical to those of the two types of total lipids at the end of growth (table 5).

TABLE 5

Fatty acid composition of total carcass lipids (mean values shown in p. 100 of methylic esters assayed)

\begin{tabular}{|c|c|c|c|c|c|c|c|c|}
\hline $\begin{array}{l}\text { Slaughter } \\
\text { weight }(\mathrm{g})\end{array}$ & Lots & $C_{14: 0}$ & $C_{36: 0}$ & $C_{1 B: 1^{*}}$ & $C_{18: 0}$ & $C_{18: 1^{*}}$ & $C_{18: 2 \omega 6}$ & $\begin{array}{l}\mathrm{C}_{20} \text { and } \mathrm{C}_{22 * *} \\
\text { polyunsaturated }\end{array}$ \\
\hline \multirow{2}{*}{300} & L & 2.0 & 29.8 & 5.1 & 7.4 & 46.6 & 7.5 & 1.6 \\
\hline & $S$ & 1.0 & 16.8 & 3.1 & 4.5 & 28.0 & 45.6 & 1.0 \\
\hline \multirow{2}{*}{250} & $L$ & 2.2 & 27.6 & 4.6 & 8.2 & 50.2 & 7.2 & $<1.0$ \\
\hline & $s$ & $<1.0$ & 14.3 & 1.6 & 5.7 & 31.6 & 46.8 & $<1.0$ \\
\hline \multirow{2}{*}{200} & $\mathbf{L}$ & 1.3 & 29.0 & 1.6 & 18.2 & 35.1 & 9.2 & 5.6 \\
\hline & $S$ & 1.0 & 15.5 & 1.4 & 8.4 & 29.5 & 39.9 & 4.3 \\
\hline
\end{tabular}

${ }_{\omega_{7}}$ and $\omega_{9}$ mixture (see table 1).

$*_{*}^{\omega 7}$ Especially $C_{20} \omega_{0}, C_{20}: 5 \omega_{3}, C_{22}: 5 \omega 3$, and $C_{22}: 6 \omega_{3}$. 
From $250 \mathrm{~g}$ to $200 \mathrm{~g}$ catabolized fatty acid mixtures have somewhat different compositions than those of total body lipids at $250 \mathrm{~g}$. The increase in amounts of oleic acid $\left(C_{18: 1}\right)$ in lot $L$ and of linoleic acid $\left(C_{18: 2}\right)$ in lot $S$ are to be particularly noted. In both cases, there is less stearic acid $\left(C_{18: 0}\right)$ in the mobilized mixtures than in body lipids at $250 \mathrm{~g}$. However, since these slight differences appear when lipolysis is less intense, this phenomenon does not affect the overall composition of the mobilized fatty acid mixture during the total weight loss period (300 to $200 \mathrm{~g}$ ).

TABLE 6

Fatty acid composition of carcass phospholipids at $250 \mathrm{~g}$ (values shown in p. 100 of methylic esters assayed)

\begin{tabular}{lccccccc}
\hline Lots & $C_{14: 0}$ & $C_{16: 0}$ & $C_{16: 1^{*}}$ & $C_{18: 0}$ & $C_{18: 2^{*}}$ & $C_{18: 2 \omega 6}$ & $\begin{array}{c}C_{20} \text { and } C_{22^{* *}} \\
\text { polyunsaturated }\end{array}$ \\
\hline $\mathrm{L}$ & 2.2 & 24.7 & 1.2 & 17.3 & 22.4 & 13.6 & 18.6 \\
\hline $\mathrm{S}$ & $<1.0$ & 22.2 & 1.4 & 21.2 & 16.0 & 21.3 & 17.9 \\
\hline
\end{tabular}

* $\omega 7$ and $\omega 9$ isomere mixture (see table 1 )

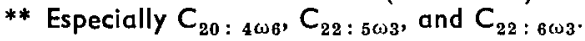

In general, when the $300 \mathrm{~g}$ non-obese rat loses about $33 \mathrm{p} .100$ of its weight, the composition of the whole of the catabolized fatty acids expresses the fatty acid composition of total carcass lipids at the beginning of weight loss.

TABLE 7

Composition of catabolized fatfy-acid mixture (values shown in p. 100 of the whole of the fatty acids mobilized)

\begin{tabular}{|c|c|c|c|c|c|c|c|}
\hline Periods & Lots & $C_{14: 0}$ & $C_{16: 0}$ & $C_{16: 1}$ & $C_{18: 0}$ & $C_{18: 1}$ & $C_{18: \omega 6}$ \\
\hline \multirow{2}{*}{$300-250$} & $L$ & 1.9 & 31.1 & 5.4 & 6.9 & 44.5 & 7.7 \\
\hline & $S$ & 1.4 & 17.8 & 3.7 & 4.0 & 28.0 & 45.1 \\
\hline \multirow{2}{*}{$250-200$} & $\mathbf{L}$ & 2.7 & 27.4 & 6.5 & 2.5 & 59.3 & 6.0 \\
\hline & 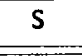 & - & 13.6 & 1.1 & 3.9 & 33.0 & 51.2 \\
\hline \multirow{2}{*}{$300-200$} & $\mathbf{L}$ & 2.1 & 30.1 & 5.7 & 5.7 & 48.5 & 7.2 \\
\hline & $S$ & 1.1 & 17.0 & 3.2 & 4.0 & 28.9 & 46.3 \\
\hline
\end{tabular}

\section{Discussion.}

In our experimental conditions, using our method of energy restriction, we found no difference in weight loss rate between the two lots of animals studied. A high quan- 
tity of linoleic acid (45.6 p. 100 of total fatty acids) in the body lipids cannot thus be considered as a factor slowing down weight loss in the $300 \mathrm{~g}$ non-obese rat.

The patterns of different "protein, lipid and water 》 body compartments are similar in the two lots. Firstly, weight loss is the result of a high mobilization of lipid stores and low water elimination. Secondly, lipid store mobilization slows down, water loss is high and proteolysis is intense. In this study animals fed sunflower-seed oil were slightly fatter at the beginning of the weight loss period. As compared to the controls they were characterized by higher body lipid mobilization from 300 to $250 \mathrm{~g}$. The « water » compartment thus played a lesser role in weight loss during this period. A high concentration of linoleic acid in the "lipid " compartment did not slow down lipid mobilization in lot $S$ rats. Lipid balances made during weight loss showed that 90 p. 100 of neutral lipids are mobilized, while only 20 to 25 p. 100 of phospholipids are degraded. The amounts of unsaponifiable carcass lipids do not alter significantly during weight loss. The role played by lipids during mobilization is comparable in both lots.

As compared with observations made in growing animals of the same weights, rats having been subjected to energy restriction resulting in a large weight loss, exhibit different body compositions. The data of Durand, Fauconneau and Penot (1967) and Desmoulin (1967) show that growing animals at a weight of $250 \mathrm{~g}$ and $200 \mathrm{~g}$ are characterized by much higher lipid content and by lower water and protein contents.

The compositions of mobilized fatty acid mixtures, as provided by fatty acid balances during both energy restriction periods, show that catabolization of fatty acids is not affected by the amount of linoleic acid in adipose tissue. During the whole weight loss period and whatever the linoleic acid concentration, the overall composition of the mobilized fatty acid mixture significantly ressembles that of the initial lipid stores. In spite of its essential fatty acid character, linoleic acid thus plays a role, like other fatty acids, in covering the energy needs of the animals with an energy restriction. As compared to other fatty acids, its action is directly proportional to its concentration in the adipose tissue.

To observe a significant change in body fatty acid composition, a weight loss of about 33 p. 100 must be induced in the young, non-obese male rat weighing $300 \mathrm{~g}$.

These conclusions need a few comments. Our results were obtained by a balance method and over a long period of energy restriction. They first of all contradict those obtained by some authors (Jacquot ef al., 1959) as concerns possible slower mobilization of adipose stores when concentrations of polyunsaturated fatty acids are high in adipose deposits. They also disagree with the hypotheses of mobilization or preferential degradation of some fatty acids in adipose stores (Hilditch and Pedelfy, 1940 ; Imaichi et al., 1963 ; Meinertz, 1964 ; Raulin and Launay, 1964 ; Raulin et al., 1965). However, they confirm and complete the work of other authors, such as Longenecker (1939a) who thought that long-chain fatty acids $\left(\geqslant C_{14}\right)$ in rat were all catabolized in the same way and that only medium-chain fatty acids were preferentially catabolized (Longenecker, 1939b). This has been contested by other authors (Bezard and Bugaut, 1969). Our work also confirms that of Stein and Stein (1962) who employed an in vivo incubation technique using radioactive precursors. They showed that fasting induced 
palmitic $\left(C_{16: 0}\right)$, oleic $\left(C_{18: 1 \omega 9}\right)$ and linoleic $\left(C_{18: 2 \omega 6}\right)$ acid mobilization and that adipose fatty acid composition did not change.

Finally, the phonomenon does not seem specific to rat since Hirsch (1961) reports that adipose tissue fatty acid composition remains stable in obese man losing from 115 to $75 \mathrm{~kg}$ in 70 days ; there is thus non preferential catabolism of linoleic acid.

Accepté en novembre 1976.

Acknowledgments. - This report was financed by the INSERM as part of its program on "Lipogenesis in Mammals" (no 19). We also wish to thank Dr. G. Durand and Dr. G. Pascal for their cooperation and advice.

Résumé. L'évolution biochimique de différents compartiments corporels (eau, lipides et protéines), et plus spécialement celle des réserves lipidiques, est étudiée chez deux types de jeunes rats mâles non obèses subissant une décroissance pondérale les menant de 300 à $250 \mathrm{~g}$, puis de 250 à $200 \mathrm{~g}$. Les animaux des deux lots diffèrent entre eux par leur teneur respective en acide oléique $\left(C_{18: 1 \omega \theta}\right)$, et en acide linoléique $\left(C_{18: 2 \omega \theta}\right)$ (alimentation de croissance contenant du saindoux ou de l'huile de tournesol). En employant le même protocole de restriction énergétique, on obtient dans les deux lots la même cinétique de décroissance pondérale. On retiendra que, sur le plan biochimique, les deux périodes successives d'amaigrissement se différencient nettement l'une de l'autre, mais apparaissent de la même façon chez les deux types d'animaux. Pour ce qui concerne les lipides corporels, entre 300 et $200 \mathrm{~g}, 90$ p. 100 des lipides neutres et 20 p. 100 des phospholipides sont catabolisés, tandis que les teneurs en lipides insaponifiables restent stables.

Sur l'ensemble de la période expérimentale, les compositions centésimales des mélanges d'acides gras catabolisés reflètent parfaitement les compositions initiales des deux types de réserves adipeuses. II n'y a pas de catabolisme préférentiel visant à épargner certains acides gras au détriment d'autres acides gras. L'acide linoléique, malgré son caractère essentiel, paraît être catabolisé de la même façon que l'acide oléique en cas de restriction de l'apport énergétique. La présence d'une concentration élevée d'acide linoléique dans les lipides corporels ( 45 p. 100 des acides gras totaux), résultant d'une alimentation contenant 20 p. 100 de l'apport énergétique sous forme d'huile de tournesol, ne semble pas être un facteur nutritionnel susceptible de modifier le déroulement de la décroissance pondérale ainsi que celui de la lipolyse.

\section{References}

BEZARD J., BUGAUT M., 1969. Composition en triglycérides et en acides gras du tissu adipeux périrénal de Rats recevant de l'huile de coprah. Mobilisation en fonction du jeûne ef du froid. J. Physiol., 61, 224.

DEMARNE Y., TOURE M., FLANZY J., LECOURTIER M. J., 1975. Influence du degré d'insaturation des lipides alimentaires sur la croissance et la lipogenèse chez le Rat. Nutr. Metab., 19, 28-40.

DESMOULIN B., 1967. Evolution selon l'âge et le poids de la composition corporelle du Rat blanc soumis à un rationnement énergétique après le sevrage. Ann. Biol. anim. Bioch. Biophys., 7, 281-293.

DURAND G., FAUCONNEAU G., PENOT E., 1967. Croissance des tissus du Rat et réduction de l'apport énergétique de la ration; influence sur la teneur en acides nucléiques. Ann. Biol. anim. Bioch. Biophys., 7, 145-155.

FOLCH J., LEES M., SLOANE-STANLEY G. H., 1957. A simple method for the isolation and purification of total lipids from animal tissues. J. biol. Chem., 226, 497-509. 
HILDITCH T. P., PEDELTY W. H., 1940. The influence of prolonged starvation on the composition of pig depot fats. Biochem. J., 34, 40-47.

HIRSCH J., 1961. Composition of adipose tissue, 89-90. In L. W. KINSELL, Proc. of Devel Conference on lipids : Adipose tissue as an organ, Thomas C. C.

MAICHI K., MICHAELS G., HOLTON S., KINSELL L., 1963. Plasma lipids fatty acids during fasting. Am. J. clin. Nutr., 13, 226-231.

JACQUOT R., ABRAHAM Y., RAVEUX R., BRUNAUD M., TREMOLIERES J., 1959. Mobilisation des graisses de réserves suivant la nature des graisses alimentaires chez le Rat. Nutr. Diefa, 1, 221-226.

KATES M., 1972. Techniques of lipidology. Isolation, analysis and identification of lipids. North-Holland Publ. Co., Amsterdam, London.

LONGENECKER H. E., 1939a. Deposition and utilization of fatty acids. Fat synthesis from high carbohydrate and high protein diet in fasted rats. J. biol. Chem., 128, 645-658.

LONGENECKER H. E., 1939b. Deposition and utilization of fatty acids of low molecular weight and a fatty-acids analysis of coconut oil. J. biol. Chem., 130,167-177.

MEINERTZ H., 1964. Fatty-acids specificity of epinephrine induced lipolysis in adipose tissue. Proc. of the 6th International Congress of Biochemistry. Abst. VII, 102.

RAULIN J., LAUNAY M., 1964. Conditions permettant la rétention préférentielle d'acide linolénique, dans le tissu adipeux de Rat incubé in vitro en présence d'adrénaline. C. R. Acad. Sc. Paris. 258, 6542-6545.

RAULIN J., LAUNAY M., JACQUOT R., 1965. Indications of in vitro and in vivo $\alpha-\alpha^{\prime}$ specificity of rat epididymal lipase under epinephrine stimulation. Applications. J. Am. Oil chem. Soc., 42, $132 \mathrm{~A}$.

STEIN Y., STEIN O., 1962. The incorporation and disappearance of fatty acids in the epididymal fat pad studied by the in vivo incubation technique. Biochim. biophys. Acta, 60, 58-71. 